\title{
Worlds of Curriculum Making: Familial Curriculum-Making Worlds and School Curriculum-Making Worlds
}

\author{
Sean Lessard \\ University of Regina \\ Canada
}

\begin{abstract}
This paper explores familial and school curriculum-making worlds as conceptualized by Huber, Murphy, \& Clandinin (2011). Through inquiry into the experiences of Donovan, an aboriginal youth from an earlier narrative inquiry, this paper explores his multiple worlds of curriculum making that he composes alongside his family and community. It is through inquiry into Donovan's multiple worlds of curriculum making that his life-making experiences become more animate and visible, thereby creating possibilities to further understand curriculum-making worlds, both in and outside of school places.
\end{abstract}

As I think in the present about the stories I shared with Elder Bob Cardinal on various theories and ideas I was learning at the university, I recall times when he asked me questions about school and I would excitedly respond, eager to share. One day, as we worked together on his land preparing for ceremony, he said, "That is good what you are learning ... but don't forget about my granddaughter when you teach her at the school." My thoughts were, "How could I forget her? I see her all the time." While I wondered what he meant by this, and why he said it in this way, he slowly started to share a story with me. He began his story with questions, like he so often does. It is his way of getting me to slow down and think in a different way. "Sean, when you speak, you talk up and down, how people go from one level to another in their lives. ... Well what if I teach her in a circle? The way I teach my granddaughter is by starting in the South ... where the grandmothers are. It is where wisdom is." He took his hand and, with his finger, began to draw in the air. He painted an imaginary line moving to the west and said, "Sean, in the west, it is where bear and knowledge live ... that is my four directions teachings ... that is how I teach my granddaughter each day."

Elder Bob then brought his hand from the point in the west and drew the next part of his circle in the sky, as he moved slowly with his finger to the north. "Sean, in the north, in the 
north that is where buffalo and responsibility reside ... that is my four directions teachings ... that is how I teach my granddaughter each day." His hand now moved in a gentle way, in a soft way, slowly and purposefully, he brought his finger down forming that familiar circle shape. "Sean, in the east, in the east that is where eagle and wisdom lives. ... and that is maybe someday where I will go ... that is how I teach my granddaughter each day ... that is my four directions teachings." At this time he slowly closed the circle ... moving his hand down ... his finger moved to another place on the skyline painting that he was creating in his teaching.

"Sean, in the south, in the south we always go back home to the grandmothers ... that is how I teach my granddaughter each day ... it is my four directions teachings. Sean this is how I teach her. Now don't forget about her in school. ... Don't forget about her in school now" he said, as he smiled and looked at me. I think about that story often and I share it when I can because it stays with me as I think about the lives of people, their stories and my stories in relation to them. (Interim research text, Fall, 2013)

Elder Bob Cardinal and his teachings may be considered just stories from an aboriginal man. ${ }^{i}$ However, I see his teachings differently. His teachings sustain many people in various ways; they are not just stories in this way. While some might suggest the teachings from Elder Bob Cardinal are just fables; to others, like his granddaughter and people within his community who are taught by looking at the world quite differently than through, or with, the dominant discourses, his teachings are what matters. The stories Elder Bob shares are based on intergenerational teachings that he has come to know and which he passes on in the present, while always being mindful of the future and what is yet to come.

I wonder with my story of Elder Bob Cardinal and his granddaughter and think about how I had so excitedly shared the theories I was learning at university and the subject matter from school places. Elder Bob Cardinal asked me to not forget other ways of thinking about the world and, in particular, to remember his granddaughter and what he was teaching her in a place outside of school, also a place of knowledge. There is a separation between these places inside and outside of schools, often a great divide. In this moment of looking back at this experience alongside Elder Bob I can see how much it matters to attend to multiple places. In this paper, I carefully reflect on what is being asked of me by Elder Bob Cardinal when he says, "Don't forget about my granddaughter, when you teach her at school."

\section{Awakening to Curriculum Making}

During my doctoral research I came to increasingly understand curriculum in a different way from what I at first thought. I was uncertain about the concept and its broader meaning, as I had previously thought of curriculum as a program of studies, the indicators and outcomes of subject matter. This understanding of curriculum was what I came to know through my early university studies and later in my work as a teacher in schools. Thinking back to earlier interactions around the concept of curriculum, which I thought of as the document that prescribed my teaching, I now see how much this document governed both what, and how, I taught.

My shift in understanding curriculum was a slow process, an inward turn that occurred over time. During this shift I became more awake to other possibilities around curriculum and its multiple meanings. This occurred through my studies in narrative inquiry as both phenomenon and research methodology and, through the discourse I engaged in around scholarly works that caused me to pause and reconsider my previous interpretations. In Places of 
Curriculum Making (2011), Huber et al. take a reflective turn to draw on some of the ways curriculum scholars have conceptualized curriculum over time. Earlier, Connelly and Clandinin (1988) also looked across the field of curriculum scholarship and did something similar. The tradition of curriculum scholarship in which Connelly and Clandinin engage traces back to the work of Schwab (1973) and further back to the work of Dewey. The work in this tradition is grounded in Dewey's (1938) theory of experience as education. For Dewey, experience, with its two criteria of continuity and interaction, is education. While schooling is sometimes educational, education is so much more than schooling. It is with this latter thought that I turn my attention back to the words of Elder Bob Cardinal when he shared with me the ways in which he teaches his granddaughter outside of school and how the teachings outside of school are deeply educative and connected to previous knowledge that he has come to know and now passes on in the present.

Returning to the discussion around curriculum scholarship, it is evident from the work of Connelly and Clandinin (1988) that they wanted to shift the conceptualization of curriculum as a course of study as they drew attention to Schwab's (1973) four curriculum commonplaces, that is, teacher, learner, subject matter, and milieu. They conceptualized curriculum as being made in the intersection(s) of these curriculum commonplaces. Working from Dewey's fundamental ideas of experience and Schwab's ideas of curriculum, Clandinin and Connelly (1992) explained curriculum could be understood as a course of life being composed in schools as the lives of teachers and students met with one another and in relation with subject matter, within a nested set of milieus or contexts. Teachers and children made curriculum together; that is, teachers were curriculum makers alongside children in classrooms.

These theoretical concepts of curriculum shaped further studies with both teachers and children and youth in multiple landscapes, which provided possibilities for understanding curriculum making within school places. Huber and Clandinin $(2002 ; 2005)$ continued to develop ideas in relation with curriculum as a course of life as they conceptualized a "curriculum of lives." However, in these studies curriculum as a curriculum of lives was seen as the meeting of lives in schools; their focus was firmly on curriculum making as occurring in schools. In 2011, Huber et al. began to understand from their studies alongside children, families, and teachers, both in and out of schools, that curriculum making was not only situated in schools but was also situated in family and community places. As they worked with children, families, and teachers, they realized that in home places and in communities, curriculum was also being made, and that it was important to name these interactions as curriculum making. I now wonder, as I think with my stories of Elder Bob Cardinal and his granddaughter, about the richness of the experiences shared between them, from within community places that are inter-generational and contextual, and this is what I imagine as a kind of curriculum making that takes place outside of school.

Huber et al. (2011) continued to draw on Schwab's four commonplaces to demonstrate that the four curriculum commonplaces can also be used to think about the curriculum making that happens outside of schools as children and families compose their lives. As Huber et al. realized, from the child or learner's point of view, these different places of curriculum making constituted different worlds in Lugones' (1987) sense of worlds and world travelling. Using Lugones' concepts, Huber et al. make clear there are two distinct worlds of familial curriculum making and school curriculum making. Each day, children metaphorically and physically move from their familial worlds of curriculum making to their school worlds of curriculum making and back again. I sense that Elder Bob Cardinal was also trying to highlight this movement to me as 
he asked me to continue to think about the experiences of his granddaughter both inside and outside of school. It was within the midst of this tradition of curriculum scholarship that I continued to expand upon my earlier understandings of curriculum as I engaged in doctoral research: A Narrative Inquiry into the Experiences of Aboriginal Youth and their Families in Urban Settings (Lessard, 2014).

\section{Narrative Inquiry}

As I came to this narrative inquiry as a beginning researcher, I held many puzzles around the experiences of aboriginal youth, of their lives both in and outside of school. Through my job on a school board as an aboriginal consultant, I was often involved in policy discussions around graduation rates and increased outcomes for aboriginal student learners within the context of school. However, the context of policy discussions and programming rhetoric often situated aboriginal youth and their families in deficit positions, far removed from the possibilities that might be imagined both in their lives and within places other than school.

Within my graduate program I came to further understand curriculum as a life-making process through my studies in narrative inquiry. I came to understand narrative inquiry as both research methodology and a way to understand the phenomenon of experience (Clandinin \& Connelly, 2000). As Connelly and Clandinin (2006) write,

People shape their daily lives by stories of who they and others are and as they interpret

their past in terms of these stories. Story, in the current idiom, is a portal through which a person enters the world and by which their experience of the world is made personally meaningful. Narrative inquiry, the study of experience as story, then, is first and foremost a way of thinking about experience. Narrative inquiry as a methodology entails a view of the phenomenon. To use narrative inquiry methodology is to adopt a particular view of experience as phenomenon under study. (p. 375)

Thinking narratively is now how I think with stories shared in relation over time, stories that are told of experiences in both in and out of school places alongside youth and their families on multiple landscapes. In this way narrative inquiry is the phenomenon as I think with these storied experiences. I think of walking alongside youth and their families and how, through the inquiry process, our stories become more alive between us. We learn by telling our stories in the relational spaces of narrative inquiry. The sharing of stories and the hard work of inquiring into them is demonstrated in the pragmatic example of starting with the narrative experience of coming alongside Elder Bob Cardinal at the beginning of this paper. It is through this sharing that I continue to ponder the phenomenon of experience and how experience shapes our relationship long after the initial conversation occurs.

Through my early interactions as a narrative inquirer and through the process of coming alongside youth in my graduate research, I began to hear youth tell their stories. At the same time I was beginning to tell my stories. I was beginning to better understand the concepts and the language that shaped my inquiry process alongside the youth. Working within the threedimensional narrative inquiry space, with the dimensions of temporality, sociality, and place (Clandinin \& Connelly, 2000), we, the youth and I, learned to tell stories of our lives. When I went away from those sharing places to read and re-read the field texts (Clandinin \& Connelly, 2000), I began to inquire into the stories within the three-dimensional narrative inquiry space. Clandinin and Connelly (2000) and other scholars who draw on their work helped me, as a researcher, to further understand and reflect on the inquiry process when they explain: 
As we worked within the three-dimensional narrative inquiry space, we learned to see ourselves as always in the midst located somewhere along the dimensions of time, place, the personal, and the social. But we see ourselves in the midst in another sense as well; that is, we see ourselves as in the middle of a nested set of stories-ours and theirs. ( $\mathrm{p}$. 63)

The first part of this quotation turns my attention to the three-dimensional narrative inquiry space: temporality, sociality, and place (Clandinin \& Connelly, 2000). The second part draws my attention to the relational aspect of narrative inquiry and how, as I engage with participants, there is a co-construction of our stories.

Going back to my doctoral work and in particular to the narrative account co-composed with Donovan, one participant within the study helped me to continue to attend to the lives of youth differently; this process supported me to become more awake to the curriculum making that is taking place on multiple landscapes. In this way I came to think more carefully about who I am in relation with the youth with whom I continue to work both inside and outside of schools in the present. I am understanding that our stories are contextual and that inquiring into the details that shape our relationship is important. To make these aspects of the inquiry process more visible, I now turn to an initial experience of coming to know Donovan, an experience that stays with me.

\section{Learning to Listen to What I Could Not Hear}

I first met Donovan at the $U$ of A art club, a Wednesday afternoon research space for 2 years in an urban junior high school. I remember him as young man who filled the room with his smile. His humour and laughter were gifts. He had a gentle presence. As I reflect on memories and read my field notes in the present, I see him in my mind as he flashes a smile, and I recall him sharing his stories of "taking care" of his newborn baby niece. I learned early on how important his family members were to him. He showed me many photographs as he let me into his world. ... flipping through his phone, in another way telling me stories that he was a proud uncle, brother, grandson, and son.

As I write these words my memories flash backwards and forwards as I think of the stories and experiences we shared over time. I think of Donovan and his drum, one that he created alongside an Elder, and how he played it with a certain rhythm in different places. The drum is part of a process when I think of it in this way. It is animate and living. I see Donovan through the memories of our early beginnings and I fondly recall his presence, but I also see him as he is carrying songs and teachings through his drum.

I slip back in time and recall being told by the other researchers that Donovan first came to the $U$ of A art club research space, perhaps somewhat reluctantly, following closely behind his older sister. The stories that were shared were that Donovan was often led by his older sister and that she was always looking out for her little brother, like big sisters sometimes do. Stories of Donovan were often composed through those early interactions as a boy on the margins, on the periphery. It was as if he was connected but disconnected as he remained at a distance to many of us. I was uncertain, as I recall, where our relationship would take us, uncertain if it would develop at all.

As I came to know Donovan we connected with brief verbal exchanges, a high five or a pat on the back that later led to a good meal and conversation. We met at the art club space as we came to understand and trust one another with more certainty. Our relationship developed over careful time and through the symmetry between friends as I came to know Donovan through 
his friend Lane and Lane through his friend Donovan. (Excerpt from narrative account, Lessard, 2014)

I share this particular excerpt from a narrative account to make visible aspects of Donovan's life, letting the reader in by sharing my reflections of an inquiry process that took place over two years. As we worked together I realized there were important details that I, as a researcher, was missing. It became imperative to attend to multiple places over time as I began to understand some of Donovan's experiences, many of what I could not see initially. Donovan had a quiet presence and through the research conversations he eventually shared with me what he knew from other places like his home, community, and family. Despite our shared Cree heritage there are intricate details and protocols from within our communities, and from within our experiences, that are far different. Donovan had learned to keep many stories silent on certain landscapes, especially within the context of schools and those who he might perceive as being connected to schools. Only by attending to the life of Donovan and inquiring into his experiences attentive to temporality, sociality, and place(s) did I gradually come to understand and learn in deeper ways alongside him.

Over our time together in the research, Donovan began his journey in learning how to make a drum alongside an Elder. Through this process of creating and learning he began to recall details from his own community, and slowly the teachings, the knowledge nested deeply within him from these places became more visible in our research conversations. Through the process of creating a drum and learning to play songs that accompany the drum, Donovan began to share stories of his homeplace and other places outside of school, in particular the stories that are sometimes difficult to travel to. Donovan has experienced great loss in his life, and he longed dearly for the dirt roads of his community that he used to travel as a young boy to visit his Elder and to visit his Grandma, Kookum Muriel.

Alongside these experiences within Donovan's life I was able to think about experiences that shape me...experiences that stay with me and linger in the present. In a similar sense I continue to travel metaphorically to the stories of Elder Bob Cardinal and his granddaughter as a reminder to think about the knowledge that is situated in place and the multiple worlds of curriculum making both inside and outside of schools.

\section{World Travelling Between Worlds of Curriculum Making}

As I continue to think about the youth and families with whom I work in schools, I recognize there is a sharp contrast between the worlds of familial curriculum making and school curriculum making. Many youth I know travel to school each day on multiple busses with different routes or for many hours from the reserve to the urban setting and the school world of curriculum making. As the youth physically travel they begin to recognize within themselves the necessary changes required to participate in a place that is different from what they have known. The world of school curriculum making is different from the world they leave each morning within their community, within their homes alongside families. For them, travel to school constitutes world travel. Through the research conversations, and my reflections on them, the two worlds of curriculum making have become more visible to me: I recognize that the youth and their families are aware of how they construct themselves, and are constructed by others, in these two different worlds of curriculum making. Participating in the world of school curriculum making requires that they give up, or shift, who they are in order to participate. When the youth return to the world of familial curriculum making, they often have to shift again, from who they 
were in the school curriculum-making world. Lugones (1987) describes this phenomenon in the following way;

In a "world" some of the inhabitants may not understand or hold the particular construction of them that constructs them in that "world". So, there may be "worlds" that construct me in ways that I do not even understand. Or it may be that I understand the construction, but do not hold it of myself. I may not accept it as an account of myself, a construction of myself. And yet, I may be animating such a construction. (p. 10) Through the experiences shared alongside Donovan, I heard stories of his dis-ease and discomfort (Lugones, 1987) in the travel between the familial and school curriculum-making worlds and in the construction of who he was within these worlds.

As now I look across the narrative account co-composed with Donovan as he participated in the research, I continue to think with curriculum and in particular with the curriculum commonplaces (Schwab, 1973). I revisit the concepts of curriculum to help me further understand the experiences of aboriginal youth and their families in urban school settings. Reflecting on Schwab's four curriculum commonplaces alongside the experiences of Donovan and his family helps make visible the familial and school curriculum-making worlds within their lives, while also showing their experiences of travelling to and in-between these worlds.

\section{Subject Matter}

"I hardly miss a day of school Sean. I want to play solo for morning song," he told me. I recorded this conversation and I reflect on an amazing gift that is difficult to capture with written words. Our conversation moved to the words of the drum songs that he learned at Beaver Hills' House School and how he looks forward to his own songs one day. He shared, "When I close my eyes and I am singing beside Mr. Whiskeyjack, the words just come. I can remember them when I play my drum with him." With these words I asked Donovan if he could share with me "what this sounds like, what are the words that you are learning?" He began to sing quietly, softly, as he shared his songs with me, his stories. Hey Haw Hey Haw Hey Haw Hey Haw. (Field notes, Donovan, 2014)

Subject matter as conceptualized by Schwab links to the disciplinary knowledge of physics, biology, history, literature, and mathematics (1973). However, subject matter in Donovan's familial curriculum-making world revolves around his life experiences. I learned through the sharing of his stories what it is was like for him to attend Cree ceremonies at a very young age and how he understood what it meant to live in this way, within these places of teaching. The subject matters were the ceremonies but also the way of living within the ceremonies, which included the language and protocols of working in relation with people from his community. The experience of receiving the name First Thunder in a family and community ceremony is also subject matter in his familial curriculum-making world, as is drumming, picking berries, gathering medicines, and the cartography experienced in different places.

As I foreground subject matter in Donovan's experiences of travelling in and between the two worlds of familial and school curriculum making, I see there are silences in the spaces of subject matter between the familial and school curriculum-making worlds. Unspoken stories of familial curriculum making are held closely within Donovan as he, and his family, recognize the safe places where they can share stories. Often their stories of subject matter from the familial curriculum-making worlds are not shared or made visible in school curriculum-making worlds. 


\section{Teacher}

I saw Donovan today at Beaver Hills' House School and there was a calmness within him as he had found a place where possibilities exist. The staff called him "Little Francis" in honour of the Elder with whom he spends much time. They said, "We often see Donovan right beside Francis." This, to me, was special and I saw it as I went for a visit to attend the morning song that takes place each day at this school. Donovan, and other students that work with Elder Francis Whiskeyjack, drummed alongside the staff in a morning song...each day they sing for all the creatures and the animate things in this world to wake up and be thanked as gifts of creation. It was a powerful part of the day that Donovan was involved in. He said, "It sets me up for the day. I just close my eyes and I know the words." It was his routine, a part of his rhythm, to start by singing with his heart and reflecting on all the good things. (Field notes, Donovan 2014)

The teacher in Schwab's conceptualization of curricular commonplaces are those who teach (1973). When curriculum making is situated in schools, often teachers and administrators are seen to be the teachers. Rarely are other students or other beings seen to be teachers. In familial curriculum-making worlds, there are many more teachers.

As I reflect on Donovan's narrative account, I think about how it was rare that conversations with teachers and schools were considered; that is, rarely were teachers and school curriculum making mentioned. The teachers in the familial curriculum-making worlds of Donovan and his family were intergenerational knowledge keepers. Images of teachers come to mind, images of Kookum Muriel, Elder Francis Whiskeyjack, and the teachers from the homeplace community within Donovan's familial curriculum-making world.

Teachers in the stories of familial curriculum making became visible to me through the stories Donovan lived and told alongside me. Many of Donovan's stories were connected to places outside of school landscapes. As he moved between schools, at times his school curriculum-making worlds shifted. Donovan changed schools between Grades 8 and 9 as he moved to Beaver Hills' House School, a place where culture is an important part of school curriculum making. In this school curriculum-making world, Elder Francis Whiskeyjack is a teacher and someone who teaches what is often also taught in Donovan's familial curriculummaking worlds. Elder Whiskeyjack works alongside youth and engages in Cree teachings. He does not have a specific subject matter that is mandated by the province, the district, or the school. His teaching starts at the beginning of each day as he leads the school alongside youth in a morning song to give thanks to the Creator. In this way Donovan continues to find a space to learn from his teacher Elder Francis Whiskeyjack. In some ways Elder Francis Whiskeyjack is a teacher akin to Donovan's Kookum Muriel, an important teacher in Donovan's familial curriculum-making world. Donovan and Elder Francis Whiskeyjack are often seen walking side by side in the school and drumming side by side with their own beat on the drum that they made together.

As a teacher in Donovan's school curriculum-making world, Elder Francis Whiskeyjack was someone who helped him stay connected to his home-place as he negotiated an unfamiliar school curriculum-making world; he is a teacher who is an Elder who works in relation alongside youth by creating, drumming, and sharing stories of teachings from places familiar to Donovan and his early beginnings. These stories come from a place of experience and from a teacher who works outside classroom spaces. It is through the drum and the teachings alongside Elder Francis Whiskeyjack that a space is created where Donovan travels home to his community and to earlier memories within this place that are important in who he is becoming and to how he is composing his life in a world of school curriculum making. 
As I now look back at the stories shared of teachers in the lives of Donovan and his family, the two worlds of school curriculum making and familial curriculum making are in sharp contrast. I continue to learn by reflecting on my own experiences of teaching as I listen to the stories of different types of teachers outside the place of school. I recognize that I need to listen closely to Donovan's stories as he shares stories of his teachers within his life and with whom he interacts in different places. In many ways I have privileged the commonplace of teacher in school as the person who is responsible for the curriculum and, to a large extent, the learning and teaching of the youth. In relationship with Donovan and his family I begin to understand that the teachers within his life move far beyond those named as teachers in the place of school. It is the teachers and the interaction between Donovan and his teachers in out of school places (Huber et al., 2011) that help me understand what might be most important in the lives of youth and their families as they navigate urban school curriculum-making worlds.

\section{Milieu}

Donovan explained to me "when I hear the rain fall" that "I should think about him." Those words stop me. "I know I will," was my recorded response. "I know when I hear the rain fall I will think of you," and now in my present re-telling, that good sadness overcomes me. When thinking about a life and the young person that a research project brought me to, Ifeel overwhelmed and gifted. It was a gift when he said, "when I hear the rain fall" to me. I have an image in my mind of a young boy and how he thought with those words and his connection to his family, and the places he moved within, both geographically and metaphorically. He said to me with quiet strength. "I was told that when I hear the rain and the First Thunderi I should take some food and tobacco and bury it beside a tree to give back and remember my name."

Donovan told me his story with a small whisper of words and intermittent silences, and the pause that slowed down the conversation allowing time for reflection as he thought when he told me. (Field notes, Donovan 2014)

Milieu is the place of school within Schwab's commonplaces of curriculum that includes the dominant cultural, institutional, linguistic, and social forces that structure school (1973). As Huber et al. (2011) describe the milieu in familial curriculum-making worlds, they include both home and community places and individual family and community members who live in these places. Milieu was important in Donovan's life, which included many home-places across time. As Donovan told of home places, his milieu, he told me of people and places where he learned specific teachings that continue to shape him and that stay with him in sustaining ways. The story of First Thunder is deeply connected to the nested milieux within his stories; these are knowledge places where he learned about his identity and the intergenerational stories within his family that are sacred. In Donovan's life making, milieu is connected to place and the memories and experiences within the places that he shared with me. His stories included people and the relations that live within these places; they also included the stories that live within his memories and the stories of those who have passed and the importance of going back to places to continue to remember. Donovan's milieu are places such as the kitchen table where he played board games with his Kookum, the outside places near a tree where he is encouraged to bring an offering of food. Donovan negotiates multiple milieux as he moves between his place in the city and his ancestral home land. The stories of gathering times at pow wows and of taking care of his relations, as he was taken care of by his extended family, are present in the stories.

Donovan's stories include ongoing negotiations with how milieu is composed within multiple places. The conceptualization of milieu in the familial curriculum-making world is not 
static or fixed; it involves multiple meanings and places within Donovan's stories. Many stories become visible to me as I think of milieu in familial curriculum-making worlds and how these worlds are composed in Donovan's life. The milieux in his familial curriculum-making worlds are quite different than the milieux in his school curriculum-making worlds. His life and the people within his life are family compositions that are not as recognizable or familiar in the school curriculum-making world. Within the subject matter and in the books or posters that hang on the walls of schools, what counts as the family unit and the places where families live are far different than those Donovan lives in his familial curriculum-making world. The milieux in his familial curriculum-making world are connected to the rhythm and the response of his family and how they negotiate the for now in their stories. His family takes care of each other and holds on to each other's stories within shifting plotlines and on multiple landscapes. The milieu in the familial curriculum-making world is the composition of family and how it is connected to the multiplicity within places over time. There are fibres within these stories that weave and stretch out, over and across time and place. Milieu in Donovan's stories includes how he honours his family stories and the places that he has lived alongside family members. His stories are different than what I have known and are sustaining stories in his life of who he is and who he wants to be both in school and in outside of school places (Huber et al., 2011).

\section{Learner}

He started to tell me about walking a long distance to visit her. "Across the lake is where she lived" is how he said it. "She had a big house and she made a farm so I would play with the animals - the chickens and the horses. I would go there by myself, just walking." I see him in my mind walking down the rural roads of his community. That sense of taking care of the animals was what he enjoyed sharing with me at this time. The feeling of spending time that was free with his Kookum was what he helped me recall within my own stories. He continued his sharing moment laughing as he told me his stories of "chasing chickens" and the time his horse "head butted" him. We both laughed at these stories, as I once again recalled the good moments of improvisation and playfulness of growing up on a farm. I asked Donovan ... "Favourite all-time memory of your Kookum?" Donovan shared a story of the time his Kookum played chess with him and how she taught him board games. "She would speak to me in Cree, teaching me all my numbers and the animals but now I forget. But the best memory of her is that she would just spend time with me." (Field notes, Donovan 2014)

Learners, the children and youth within Schwab's curriculum commonplaces, are in relation to the teacher and subject matter in school (1973). Learning is dependent and determined by the relationship between the commonplaces. It is a framework for understanding how knowledge might be transferred to students in schools but at times this conceptualization struggles to create possibilities to think of how learning might be possible in places outside of school.

Huber et al.'s (2011) understanding of learner as shifting, moving, and creating in multiple places alongside others provides another perspective in how learning can be considered. The familial curriculum-making world leaves open the possibilities for the learner and honours the people and places within experiences that go beyond school and classrooms. There is multiplicity and hope with this understanding of learner as it suggests that learners are not static within this process and that there is possibility in who they are becoming beyond places of school and beyond how school might assess what has been learned. 
As I consider what learner means in the familial curriculum-making worlds of youth, I see them as aware and guided by the places of wisdom within themselves. As learners, the youth move in relation to what they are aware of from different places. I believe the learner in the familial curriculum-making world cannot be considered without thinking about embodied knowing (Clandinin \& Connelly, 1986). There is learning that occurs through the sharing of stories differently than the ways a school might conceptualize or measure learning. There is learning that takes place through observation in multiple places that occurs in the youths' familial curriculum-making worlds. Who they are as learners and what they learn are connected to the intergenerational teachings passed over time and within place(s).

I reflect on the research conversations with youth and family members from the larger study in different places over the course of two years. I heard stories that move beyond my experiences as I think about what they teach me. It is difficult to assess the learning that comes from the connection to a home-place or the stories that are passed on through the teachings that come from intergenerational places. It is difficult to assess the wind and the rain, the stones and the water, and the stories that are taught with these elements in mind. The learning that occurs within different places that guides the youth in the present is difficult to articulate with words, but it is more visible within the stories that I have listened to in relationship over time.

Donovan's role as the learner in his familial curriculum-making world is ongoing and alongside people and the stories within places that he knows. There is knowledge in his stories, as he understands the details and protocols in helping the Elder at his school prepare for the sweat lodge ceremony that occurs each month. There is knowledge in being alongside Kookum Muriel, who was guiding him his life in and outside of school places (Huber et al., 2011), helping him negotiate the complexities within landscapes. His learning is active and animate as he tells stories of creation as he teaches me in these moments of relationship.

I did not know many of the creation stories that Donovan shared with me that he had come to know in his early life. The learning through the sharing of stories becomes visible over time and through the emerging relationship; it also is present in the songs that he has come to know while learning to drum. Donovan's stories held the intimate knowledge he knows of the medicines from within his community and what it means for him to smudge each morning: cleansing himself in a way that he has been taught in a different place, taught in the most careful and respectful of ways. His life rhythm includes those moments when he is at home by himself smudging both in the morning and at night but also in the moments when he is having difficulties and wants to think in a different way.

The stories and teachings he had learned from different places continued to become visible. As we sat together, he shifted back to earlier memories of his family and, in particular, his Kookum Muriel, a significant teacher in his life. He explained some of her stories and how what she taught him long ago makes more sense to him now. "She was an Elder to everyone," he said, and through these teachings he continues to make sense of who he is in relation to what has been shared with him. The story of First Thunder, when he received his name at a very young age to honour the passing of a sibling, is becoming more prominent in his life-making. Donovan is now in a place in his life where the teachings are continuing to shift who he is becoming inside and outside of school places (Huber et al., 2011). His teachings and how he is learning is connected to earlier experiences that will not become visible in the place of school or through the subject matter in a class; these emerge through who he is becoming in relationship with the people around him and the stories that he has been taught in earlier times. These parts of his life are what matter but within the worlds of familial curriculum making and school 
curriculum making he struggles to explore and make sense of the knowledge and what counts as knowledge within each world.

\section{The Importance of Attending to Youth as World Travellers among Worlds of Curriculum Making}

Donovan's experiences continue to teach me about the knowledge that exists within the multiple worlds of curriculum making, both school and familial. I reflect on Schwab's curriculum commonplaces (1973) and the conception of familial curriculum making (Huber et al., 2011) to help me understand the layers within the experiences shared. The world of school curriculum making is an important part of life, and the youth and families recognize the importance of school within their lives as they share stories of hopes and dreams in their lives through the institution of school. The process of writing about school curriculum making and, in particular, Schwab's curriculum commonplaces is not a criticism of the important curriculum composed within schools. As a person who has taught in schools for years, and who has assisted in provincial curriculum development, I take seriously the work done in schools. Through the processes of narrative inquiry, including telling and listening to stories and co-composing narrative accounts alongside the aboriginal youth and their families, I am left with more wonders as I consider the work in which I have engaged in my adult life. I listened to many youth and families share their stories with me. As they shared with me, they took me to many of my own stories, like my story with Elder Bob and his granddaughter. As I develop my ideas alongside Huber et al. (2011) and their work in familial curriculum making, I look for more hopeful spaces between the worlds of familial and school curriculum making to help me further understand the possibilities within each world.

I do not think it is helpful to concentrate solely on parts of a life or the separation of worlds when considering conversations about curriculum making in schools. The world of familial curriculum making helps me understand the lives of youth and their stories of who they are becoming. The youth and the families in their wholeness are more visible to me when I think about the lives they are composing on multiple landscapes across time. I learn to become more responsive through the youths' stories. The youth and their families are teaching me in this way to become more attentive within the school landscapes in which I live in the present, as I try to find spaces within myself to slow down, pay attention, and listen to the stories being shared with me.

I recognize the important place school curriculum making holds within the lives of children and youth. Despite a history with schools that is complicated, the families I have walked alongside in my research value what school is teaching their children (Lessard et al., 2014). In many cases, families privilege the world of school curriculum making rather than their familial curriculum making. Many families have learned to stay silent and not question what is being taught in the world of school curriculum making. It is an uneven and disconnected relationship. I wonder about the meaning of relationship within this description. It is my hope that, through the process of writing the stories of the youth and their families, specifically Donovan and his family, I will continue to create spaces within places of school that honour and respond in respectful ways to the familial curriculum-making worlds of youth and their families. I am not looking to change the provincial curriculum or design a new aboriginal studies course or school that will try to more fully meet the needs of aboriginal youth and their families in school. Through this work my hope is continued conversations and a further understanding of the 
multiplicity within the lives of aboriginal youth and their families, inside and outside of school places.

The familial curriculum-making world moves beyond the stories of the aboriginal youth and their families that I have come to know in relation. The narrative inquiry processes, relational research processes, also reach out into different places within me as I begin to understand stories that are nested deep within myself. I continue to travel back (Lugones, 1987) to my own experiences within multiple worlds to help me understand this shift in how I am considering a curriculum of lives within the place of school. I am reminded often of the many ways of thinking about "world-travelling" (Lugones, 1987) and in particular when I sit alongside Elders who I have come to know in relation.

I turn back to the beginning story as I think more deeply about what Elder Bob Cardinal was asking me to do when I teach his granddaughter: "to not forget her." His teachings shape me. I begin to understand in different ways what he is asking from me: to value the knowledge in school places but also to value the knowledge that is composed and taught in familial curriculum-making worlds outside of school. The teachings that he has passed on to his family are situated in place and through relationships over time. His teachings as he shares them with me include multiple landscapes, with different teachers who have shared with him ways of thinking about the world as he composes a life for and with his family. I think about what Elder Bob Cardinal is saying as I have Donovan on my mind.

I took a walk out on Elder Bob Cardinal's land today; it is a place where we spend time together. It is a teaching and knowledge place that he shares with me. The trees surrounding and the wild grasses blowing, they were dancing in the wind and one might consider them the teachers within this place. If I listen to the sounds on the landscape and pay careful attention I understand differently what it is I am hearing. The rocks ... the water ... the details of the landscape can be subject matter when I think of them in this way, within this place. As I walked outside today the animate and living were all around me, as I heard as I let myself go to the silent places of reflection and turning inward. It is in this place within myself that I begin to also notice the possibilities and richness in this type of milieu. The teachers, in this place, are the wind calling and the birds communicating. I sit in this place and time is no longer a consideration as I let the sun fill my spirit and give me energy as it shines its way down and lifts me up...in this space I am a learner in a different way. It is beautiful to think of the stories that are situated in the places that I need to continue to listen to and listen for. Listening and observing, paying attention to the details of the landscape is what I so often am missing.

As I continue to write I think about the experiences in different places alongside the youth and families. I can see Donovan walking down the gravel road to remember the stories that his Elder, Kookum Muriel, taught him ... these stories keep him going, they sustain him as he continues to bring them alive through his drum and the songs he is learning.

In this moment of thinking and reflection time, I looked up to the trees surrounding and watched the leaves move, pushing back and forth through the hush of the wind. I can imagine Donovan as he is on the road again. I understand through his stories something of the landscapes of his youth and the imagery that is etched deeply within him. He has stories of places in memory where the water stretches out alongside the gravel road on the solitary walks to his Kookum's house...these are the memories that he holds deep within himself. It is the images of places that he has travelled to...in and between that sustain his stories and continue to remind him of what is important in his life. These stories hold his memories. They are his teachers. He is taking care of the stories with kindness and not forgetting about these early 
Worlds of Curriculum Making

moments of experience where the water flows and fills the landscape in different ways than I have known.

In these ways I will not forgot Elder Bob Cardinal's granddaughter. In these ways I will not forget Donovan. (Interim research text, Fall, 2013) 


\section{References}

Clandinin, D. J., \& Connelly, F. M. (1986). Rhythms in teaching: The narrative study of teachers' personal practical knowledge of classrooms. Teaching and Teacher Education, 2(4), 377387.

Clandinin, D. J., \& Connelly, F. M. (1992). Teacher as curriculum maker. In P. W. Jackson (Ed.), Handbook of research on curriculum (pp. 363-401). New York, NY: Macmillan.

Clandinin, D.J., \& Connelly, F.M. (2000). Narrative inquiry: Experience and story in qualitative research, San Francisco: Jossey-Bass.

Connelly, F. M., \& Clandinin, D. J. (1988). Teachers as curriculum planners: Narratives of experience. New York, NY: Teachers College Press.

Connelly, F.M., \& Clandinin, D.J. (2006). "Narrative inquiry," in J. Green, G. Camili, and P. Elmore (Eds.), Handbook of complementary methods in education research (pp.477487). Mahwah, NJ: Lawrence Erlbaum.

Dewey, J. (1938). Experience and education. New York, NY: Collier.

Huber, J., \& Clandinin, D. J. (2002). Ethical dilemmas in relational narrative inquiry with children. Qualitative Inquiry, 8(6), 785-803.

Huber, J., \& Clandinin, D. J. (2005). Living in tension: Negotiating a curriculum of lives on the professional knowledge landscape. In J. Brophy \& S. Pinnegar (Eds.), Learning from research on teaching: Perspective, methodology and representation (pp. 313-336). Oxford: Elsevier Ltd.

Huber, J., Murphy, M. S., \& Clandinin, D. J. (2011). Places of curriculum making: Narrative inquiries into children's lives in motion. Bingley, UK: Emerald Publishing.

Lessard, S. (2014). Red worn runners: A narrative inquiry into the stories of Aboriginal youth and families in urban settings. Unpublished doctoral dissertation, University of Alberta, Edmonton, Canada.

Lessard, S., Caine, V., \& Clandinin, D.J. (2014). A narrative inquiry into familial and school curriculum making: Attending to multiple worlds of Aboriginal youth and families. Journal of Youth Studies, 17(9), 1-18. DOI: 10.1080/13676261.2014.944121

Lugones, M. (1987). Playfulness, "world" - travelling, and loving perception. Hypatia, 2(2), 337.

Schwab, J. J. (1973). The practical 3: Translation into curriculum. The School Review, 81(4), $501-522$. 
Worlds of Curriculum Making

\section{Notes}

${ }^{i}$ The term "aboriginal" is used in this paper to represent the first inhabitants of Canada and includes First Nations, Métis, and Inuit peoples as outlined and defined in section 35 of the 1982 Canadian Constitution Act.

Sean Lessard is an Assistant Professor in Indigenous Education and Core Studies at the University of Regina. Sean's research interests include Narrative Inquiry, curriculum studies and aboriginal youth and their families both in and outside of school places. Sean's most recent work takes place alongside colleagues in the City of Regina, Saskatchewan where they have cocomposed an inter-generational curriculum making space outside of school conceptualized around wellness and the experiences of urban aboriginal youth and their families.

Email: sean.lessard@uregina.ca 